\title{
A Strange Obsession with Nazi Christianity: A Critical Comment on Richard Steigmann-Gall's The Holy Reich
}

Richard Steigmann-Gall's study of 'Nazi conceptions of Christianity' is, without question, both an interesting and provocative contribution to recent debates on religious conditions and nazi ideology in the Third Reich and, by extension, to the current controversies concerning secularization processes and the history of twentieth-century religion in general. ${ }^{1}$ These debates have been ongoing for the last 15 years, usually under the rubric 'political religion' and in the context of more recent attempts at revising the older sociological secularization paradigms. Regrettably, however, Steigmann-Gall makes far too little reference in his revised dissertation, published in 1999, to this broad and sometimes international debate. In this respect, let it be said at the outset, his contribution is not as novel, original or revolutionary as he, and some of his book-jacket reviewers - not least the three prime eulogists Richard Evans, Michael Burleigh and Helmut Walser Smith — would have us believe. ${ }^{2}$

1 Richard Steigmann-Gall, The Holy Reich. Nazi Conceptions of Christianity, 1919-1945 (Cambridge 2003). The book is based on the author's revised dissertation, “The Holy Reich”. Religious Dimensions of Nazi Ideology, 1919-1945', University of Toronto 1999.

2 See Jay Baird, To Die for Germany. Heroes in the Nazi Pantheon (Bloomington, IN 1990); Ulrich Nanko, Die deutsche Glaubensbewegung. Eine historische und soziologische Untersuchung (Marburg 1993); Hermann Lübbe (ed.), Heilserwartung und Terror. Politische Religionen des 20. Jahrbunderts (Düsseldorf 1995); Hans Maier (ed.), Politische Religionen. Die totalitären Regime und das Christentum (Paderborn 1996); idem and Michael Schäfer (eds), 'Totalitarismus' und 'Politische Religionen'. Konzepte des Diktaturvergleichs (Paderborn 1997) and Totalitarismus und Politische Religionen. Deutungsgeschichte und Theorie (Paderborn 2003); Michael Ley and Julius Schoeps (eds), Der Nationalsozialismus als politische Religion (Bodenheim b. Mainz 1997); Sabine Behrenbeck, Der Kult um die toten Helden. Nationalsozialistische Mythen, Riten und Symbole 1932 bis 1945 (Vierow b. Greifswald 1996); Yvonne Karow, Deutsches Opfer. Kultische Selbstauslöschung auf den Reichsparteitagen der NSDAP (Berlin 1997); Claus-Ekkehard Bärsch, Die politische Religion des Nationalsozialismus. Die religiöse Dimension der NS-Ideologie in den Schriften von Dietrich Eckart, Joseph Goebbels, Alfred Rosenberg und Adolf Hitler (Munich 1998); Frank-Lothar Kroll, Utopie als Ideologie. Geschichtsdenken und politisches Handeln im Dritten Reich (Paderborn 1998); Klaus Schreiner, “Wann kommt der Retter Deutschlands?" Formen und Funktionen von politischem Messianismus in der Weimarer Republik', Saeculum, 49 (1998), 1st half vol., 107-60; Gerhard Besier, 'Der Nationalsozialismus als Säkularreligion' in idem and Eckhard Lessing (eds), Die Geschichte der Evangelischen Kirche der Union, vol. 3 (Leipzig 1999), 445-78; Barbara Zehnpfennig, Hitlers 'Mein Kampf'. Eine Interpretation (Munich 2000); Wolfgang Hardtwig, 
In his introduction he notes correctly that, to date, mainstream researchers have characterized National Socialism — in terms of a movement, a regime, an ideology - as predominantly non-Christian or explicitly anti-Christian. Meanwhile, however, more recent studies have shown how heavily permeated and partially dominated by National Socialist ideas and the National Socialist disposition the main denominations were - Catholicism to a lesser extent, Protestantism more so in the form of the 'German Christians'. Starting from these well-founded research conclusions, Steigmann-Gall claims to extend these findings. According to him, not only were many (Protestant) Christians also professing National Socialists but many leading protagonists of National Socialism were (or remained) 'in some sense' (66) Christians or at the very least continued to be influenced by fundamental Christian conditioning. The thesis he seeks to prove is both bold and daring.

In this study I attempt a critical rethinking of the nature of Nazi ideology and practice and seek to uncover a dimension previously overlooked by scholars of the period. . . . I seek to add an additional layer of interpretation rather than replace or reject previous interpretations. To the many ways Nazis identified themselves and their movement - nationalist, socialist, scientific, racialist - many attached the label of Christian as well. While I chart the personal religious feelings of Nazi leaders, I seek foremost to explore the ways in which Nazis claimed their movement and its ideology were related or unrelated to different strands of Christian thought. ${ }^{3}$

Steigmann-Gall attempts to underpin his thesis in seven chapters. The first three are seen by him as an analysis of nazi 'text', concentrating chronologically on the 'era of struggle' or the phase of NS ideological conceptualization. Here he differentiates between those protagonists who adhered to a usually vague 'positive Christianity' and those, to whom he refers as 'paganists', who followed an explicitly non- or anti-Christian agenda of ideas/beliefs. Chapters 4-7 focus more strongly on nazi 'action' and pose the question if, and to what extent, the regime, once in power, succeeded in realizing the religious potential and religio-political postulates of the 'era of struggle'. In many respects, the first part is more consistent and more convincing in its argumentation, whereas the second part is often on shaky ground, afflicted by inappropriately con-

'Political Religion in Modern Germany. Reflections on Nationalism, Socialism, and National Socialism', German Historical Institute, Bulletin, 28 (Spring 2001), 3-27; Michael Rissmann, Hitlers Gott. Vorsehungsglaube und Sendungsbewußtsein des deutschen Diktators (Zurich/ Munich 2001); Stefanie von Schnurbein and Justus H. Ulbricht (eds), Völkische Religion und Krisen der Moderne. Entwürfe 'arteigener' Glaubenssysteme seit der Jahrbundertwende (Würzburg 2001); Wolfgang Dierker, Himmlers Glaubenskrieger. Der Sicherheitsdienst der SS und seine Religionspolitik 1933-1941 (Paderborn 2002); Hans Günter Hockerts, 'War der Nationalsozialismus eine politische Religion? Über Chancen und Grenzen eines Erklärungsmodells' in Klaus Hildebrand (ed.), Zwischen Politik und Religion. Studien zur Entstehung, Existenz und Wirkung des Totalitarismus (Munich 2003), 45-71. With the exception of Ley and Schoeps (eds) hardly any of the studies cited, which after all are relevant to his subject, are considered by Steigmann-Gall.

3 Steigmann-Gall, Holy Reich, op. cit., 12. 
stricted analyses, serious methodological omissions, numerous errors and other problems.

Steigmann-Gall is adamant that the inclusion in the NSDAP 1920 manifesto of a commitment to 'positive Christianity' was not merely a 'sleight of hand' born of political opportunism calculated to deceive those Germans brought up in the Christian tradition; rather, it reflected the religious self-image of former National Socialists. As evidence he cites biographical detail and relevant quotations from Dietrich Eckart, Joseph Goebbels, Dietrich Klagges, Walter Buch, Hans Schemm and, last but not least, Hitler. Further sources used show Martin Luther as a Christian-German national hero and visions of a 'completion of the Reformation' (Artur Dinter), the goal being a homogeneous (völkisch-Protestant) state religion. Doubtless such dual-faith 'Christian National Socialists' existed, probably best encapsulated in the person of the Bavarian Minister of Culture Hans Schemm who, as a result of an accident, met an early death in 1935, in Walter Buch (the NSDAP's most senior party judge) or in the later Minister of Ecclesiastical Affairs Hanns Kerrl. ${ }^{4} \mathrm{He}$ lists as the protagonists of the alternative, non-Christian philosophical wing of the party Erich Ludendorff, Alfred Rosenberg, Richard Walther Darré, the racial anthropologist Hans F.K. Günther, the educationist and 'party philosopher' Alfred Baeumler, and even the initially strongly Catholic-influenced young Heinrich Himmler. But even these ideological dogmatists did not entirely abandon their Christian stance; it was rather a question only of a 'partial rejection of Christianity'; they adhered to a positive image of Jesus, 'Christ the fighter' or 'Christ the antisemite'. They may have been stridently anti-clerical but they were not explicitly 'anti-Christian'.

These undoubtedly striking Christian-religious fundamental principles held by early NS protagonists which also appear in the journalistic rhetoric of the NS movement have been noted and discussed many times in recent research, most explicitly in Claus-Ekkehard Bärsch's 1998 study of the religious dimensions of NS ideology. ${ }^{6}$ That Steigmann-Gall fails not only to mention but also to analyse this research which is core to his subject, is utterly incomprehen-

4 See also Manfred Gailus, "Nationalsozialistische Christen" und "christliche Nationalsozialisten". Anmerkungen zur Vielfalt synkretistischer Gläubigkeiten im "Dritten Reich", in idem and Hartmut Lehmann (eds), Nationalprotestantische Mentalitäten. Konturen, Entwicklungslinien und Umbrüche eines Weltbildes (Göttingen 2005), 223-61.

5 Steigmann-Gall, Holy Reich, op. cit., 112.

6 See Bärsch, Die politische Religion des Nationalsozialismus, op. cit. Bärsch looks at the religious-Christian substance of inter alios, Dietrich Eckart, Joseph Goebbels, Alfred Rosenberg as well as Hitler; also H. St. Chamberlain, Rudolf Heß, Julius Streicher, Baldur von Schirach, Heinrich Himmler and Hermann Göring. Bärsch's summary in his very dense and complex concluding chapters is that National Socialist ideology was permeated by a 'religious dimension' which possessed the quality of a 'political religion' (343). This NS- specific religiosity was not equivalent to 'Christianity' (350). The new faith was intended to replace, perspectively, the old Christian faith. 'By a sacralization of the nation they set the disenchantment of the world against its resacralization. The essential novelty in the National Socialist religion is the making Divine of the nation which is contained in the Aryans' divine substance' (367). 
sible. Was he not familiar with it? Would it have reduced the novelty value of his intended 'revision'? There is another consideration which greatly reduces the surprising or sensational nature of his purported 'discoveries'. All the nazi protagonists belonged to a generation born between 1880 and 1910 into an empire orientated towards Christianity. What other religious-philosophical influences could they be expected to bring with them from their - mainly bourgeois/petty bourgeois - family background, school, church and upbringing, from the civil-religious cultural contexts of public morality, morals and values, than a belief system informed by Christianity in its broadest sense and the corresponding mentality and loyalty to tradition? It almost went without saying that the religious and ideological biographies and individual transformations of their faith background were informed by these influences. Against this biographical background, it would be crucial to the analysis to know how the internal worlds of the individual protagonists had been affected, between 1920 and 1940/45, by spiritual-religious revolutions, conversion and a new belief system as they navigated the course of their seemingly miraculous and intoxicating politico-social careers in power. This would have entailed reconstructing detailed religious biographies of the individuals with whom this research is concerned; yet this would have been a time-consuming analytical task which Steigmann-Gall did not carry out because the parameters of his research were far too broad.

In the second part the author concentrates, with regard to nazi 'action', more strongly on the religio-political practice of the dictatorship. The dramatic revolutionary events of 1933 are depicted as a 'religious renewal' exemplified in the ceremonies surrounding the Luther Jubilee in November 1933 (chapter 4), followed by the classic 'Church struggle' in the context of the many attempts by the German Christians and by the nazi Reich Bishop Ludwig Müller to create a centralized völkisch state Church (chapter 5), then more obscure aspects of National Socialist social policy as so-called 'Christianity of the deed' (chapter 6), and finally - so the author maintains - the crucial and sharply anti-Church religio-political reorientation from 1937 onwards by the neo-paganist 'Believers in God' Church secession movement (chapter 7).

According to Steigmann-Gall's brief conclusion: 'Christianity did not constitute a barrier to nazism. Quite the opposite: for many of the subjects of this study, the battles waged against Germany's enemies constituted a war in the name of Christianity. ${ }^{7}$ Nazism a war in the name of Christianity? As so often in his expositions, he carries his thesis too far and tends to extrapolate National Socialism as a whole from its partial reality. Above all else, it is necessary to remind ourselves, National Socialism was a war in the name of the 'Aryan-Nordic' or 'German' blood races, which had been sacralized and deified in the sense of a new religious belief. It was this ethno-religious or German faith profession that was at the heart of the 'new faith', not Christianity, not the 'old faith'.

7 Steigmann-Gall, Holy Reich, op. cit., 261. 
A passionate desire to depict 'National Socialism' as as emphatically Christian as possible runs like a thread throughout this often very densely argued book. This obsession seduces the author into a series of systematic blind spots about National Socialism as a whole, both its potential worldview as 'text' and, above all, its practice as deed and experience, as cult, ritual and symbol. Time and again he tends to over-generalize his often apposite partial findings. $\mathrm{He}$ clearly refuses to use important sources and relevant literature if they provide evidence contrary to his thesis. In addition, the study is afflicted by methodological defects and crass academic carelessness. It is for this reason that the whole of his line of reasoning goes awry. A more detailed discussion of these shortcomings will follow.

Steigmann-Gall wants too much. It is not possible to present, in the compass of a relatively short book, an accurate discursive analysis of all the nazi protagonists with reference to 'the religious aspect'. In this respect, there is no systematic analysis in the passages concerning nazi 'text': they lack a complete study of the texts' reception; they lack a proper examination of the enormous mass of relevant texts, they suffer from selective readings of the texts, and they present quotations too much in the manner of a scissors-and-paste collage. When it comes to the press, Steigmann-Gall relies almost exclusively on discoveries gleaned from newspaper cutting collections in one or two archives. This is no substitute for continuous content analysis. Whilst it is possible to prove many things by this 'method', one can also usually prove the opposite as well. Steigmann-Gall only ever finds that which fits in with his obsession. This applies in the 'Hitler case' where the now fully edited written sources up to 1933 have only been analysed in small sections. ${ }^{8}$ Text omission is at its crudest in the 'Goebbels case', presumably not least to enable as 'Christian' a presentation of Goebbels as possible. In his case, there are many thousands of pages of diaries spanning the years 1924 to 1945, which almost completely cover the period of research with few gaps; there is no similarly complete, continuous and published source material in respect of any other prominent NS leader. ${ }^{9}$ What does Steigmann-Gall make of this grand opportunity? Pretty well nothing. With the exception of a few, to some extent questionable, supporting citations from early Goebbels (acknowledged as still very Christian-Catholic, having just escaped from a very strict Catholic parental home), there is no analysis whatsoever of the Goebbels' 'text'. ${ }^{10}$ According to Steigmann-Gall,

8 Hitler's 'Speeches, Writings, Directives', February 1925 to January 1933, were published by the Institute for Contemporary History in Munich between 1992 and 2003 in 13 volumes of more than 5400 pages. They are not mentioned once in Steigmann-Gall's analysis of Hitler's 'text'. See Wolfram Pyta, 'Die Hitler-Edition des Instituts für Zeitgeschichte' in Historische Zeitschrift 281 (2005), 381-94.

9 See Elke Fröhlich (ed.), Die Tagebücher von Joseph Goebbels. Teil I: Aufzeichnungen 1923-1941, 14 vols (Munich 1997-2006); Teil II: Diktate 1941-1945, 15 vols (Munich 19931996).

10 Questionable, as he repeatedly represents quotations of the protagonist Michael Voormann included in Goebbels' novel Michael as authentic Goebbels. Unfortunately, similar inaccuracies occur frequently. Steigmann-Gall attributes authenticity to an alleged comment by Himmler ('I've 
Goebbels showed 'no diminution of his religious convictions' after the seizure of power. ${ }^{11}$ Elsewhere, he repeats that Goebbels showed 'little change in his religious attitudes' in the later years of the regime. ${ }^{12}$ Really? To substantiate this, he cites two or three sometimes unclear references to Goebbels' speeches $(1934,1935,1937)$, together with some which do not even clearly substantiate this contention. ${ }^{13}$ But Goebbels lived until 1 May 1945 and covered thousands of diary pages with his views on numerous highly relevant topics such as 'old' and 'new' faith, religions, Christianity and Judaism, churches, creeds, etc. Why has this authoritative, authentic source not been analysed at all? For example, in December 1941 Goebbels complained at length about faith, religion and Churches:

The Führer has the highest regard for Japanese religiosity which is equal in importance to genuine Japanesedom. How regrettable that we don't have something similar. Because of its constitution and spiritual structure our brand of Christianity will always be opposed to a strongly nationalistic attitude. Its whole essence is, after all, predetermined by Judaism. A religion which proceeds from the basic principle that we must love our enemies, not kill, and turn the right cheek when we have been struck on the left one is not suited as a virile example for defending the Fatherland. Indeed Christianity is a doctrine in decay. Modern man will only despise it. ... Given modern science, to be a Christian indicates a lack of intelligence. What can Christianity do for modern man? One can only marvel that Christianity's extraordinarily vague representations of the hereafter can still touch intelligent people. The ideal of the hereafter as painted by Christianity has no inner substance ... Clearly this entire doctrine must somehow be replaced in the course of the decades. ${ }^{14}$

I seriously doubt whether Steigmann-Gall's contention that Goebbels exhibited 'no diminution of his religious convictions' during the regime can be sustained by an unbiased examination of this central corpus of sources, particularly for the war years. ${ }^{15}$ (Previously Goebbels was portrayed as a protagonist of a 'positive Christianity'!)

nothing against Christianity in itself') as recalled after the war by his masseur Felix Kersten, even according it prominence as the heading of one of his chapters (218). However, the published and authentic secret talks of Himmler remain unmentioned. See Bradley F. Smith and Agnes F. Peterson, Heinrich Himmler. Geheimreden 1933 bis 1945 und andere Ansprachen (Frankfurt am Main 1974). In June 1942, for instance, in a speech to the chiefs of office in the Reichssicherheitshauptamt, Himmler proclaimed: 'We will have to finish with Christendom in an even stronger manner than up to now. We will have to finish with this Christendom, this greatest plague that was able to attack us in history and that made us weak for every fight. If our generation does not do it, I think, it will last a very long time' (ibid., 159).

11 Steigmann-Gall, Holy Reich, op. cit., 124.

12 Ibid., 232. He quotes from weak and dubious documents from 1937 and 1941.

13 Ibid., $124 \mathrm{ff}$.

14 Elke Fröhlich (ed.), Goebbels Diaries, Part II: Diktate 1941-1945, vol. 2: October-December 1941 (Munich 1996), 506ff.

15 To my knowledge no similar analysis exists, centred on a religious-historical enquiry into the Goebbels texts. For an early attempt see Hans Günter Hockerts, 'Die Goebbels-Tagebücher 1913-1941. Eine neue Hauptquelle zur Erforschung der nationalsozialistischen Kirchenpolitik' in Dieter Albrecht et al. (eds), Politik und Konfession. Festschrift für Konrad Repgen zum 60. Geburtstag (Berlin 1983), 359-414. 
The analysis of nazi 'action' is too narrowly set out. It would have been more appropriate, from a religious history standpoint, to research the constituting of the 'new faith' as a whole in order to assess the importance of the Christian aspects. Incidentally, NS religiosity was to be found not so much as text (in general, the nazis were neither faith intellectuals nor theologians!) as in the form of a mass experience, cult, ritual, as highly symbolic and sacred actions in the context of a novel NS annual calendar of festivals and 'celebrations of life' for the rites of passage. This cult cycle competed with the traditional Christian cycle of annual and life celebrations. The contours of this new religiosity revealed themselves in particular in nazi commemorations of the dead (the Day of Remembrance for the 'Movement's Fallen' on 9 November was central). Extensive literature in which the research into this self-constitution of the 'new faith' has meanwhile been examined, is not even mentioned in this study. ${ }^{16}$ But in this area in particular Steigmann-Gall should have demonstrated whether, and to what extent, Christian — or remnants of Christian - content was still present in religious expression and ceremony. It can hardly be disputed that what is at issue here is, at heart, the beginnings of a new non-Christian belief, National Socialism's 'political religion' (or however one chooses to describe the new belief model). Instead of venturing into the actual area of nazi religiosity, Steigmann-Gall is at pains to find supporting texts in private conversations between nazis, in Hitler's dubious table talk, in the memoirs and anecdotes of the nazi entourage which might perhaps provide evidence of Christian attitudes. At times he finds himself on the slippery ground of the 'what Hitler really said' literature and he does not hesitate to avail himself of the postwar memoirs of unreliable informants as 'evidence' if they support his basic thesis. ${ }^{17}$

Steigmann-Gall has good reason for concentrating on Protestantism as the philosophical point of access for nationalistic and National Socialist ideas. One can identify the contemporary National Protestant milieu — as compared with other social milieux and group cultures - as the main breach point for the 'Ideas of $1933{ }^{\prime} .{ }^{18}$ Nevertheless, Catholicism should not be so totally

16 Cf. Behrenbeck, Der Kult um die toten Helden, op. cit.; Karow, Deutsches Opfer, op. cit.; Klaus Vondung, “Gläubigkeit” im Nationalsozialismus', in Maier and Schäfer (eds), 'Totalitarismus', op. cit., 15-28; Werner Freitag (ed.), Das Dritte Reich im Fest. Führermythos, Feierlaune und Verweigerung in Westfalen 1933-1945 (Bielefeld 1997); Esther Gajek, “"Feiergestaltung”. Zur planmäßigen Entwicklung eines "aus nationalsozialistischer Weltanschauung geborenen, neuen arteigenen Brauchtums" am Amt Rosenberg', in von Schnurbein and Ulbricht (eds), Völkische Religion, op. cit., 386-408.

17 Albert Speer could not even recall the Holocaust when the war was over. The extent to which the perspective in all his 1969 'Erinnerungen' was distorted has only recently become clear during discussion prompted by Heinrich Breloers' TV documentary 'Speer und Er'; cf. also Susanne Willems, Der entsiedelte Jude. Albert Speers Wohnungsmarktpolitik für den Berliner Hauptstadtbau (Berlin 2002); Frank Schirmacher, 'Der Engel fährt zur Hölle. Breloers Film über Albert Speer', Frankfurter Allgemeine Zeitung, no. 65, 18.3.2005, 39.

18 See Thomas Fandel, Konfession und Nationalsozialismus. Evangelische und katholische Pfarrer in der Pfalz 1930-1939 (Paderborn 1997); Björn Mensing, Pfarrer und National- 
excluded from the analysis, nor exculpated as it is by the author. By doing so he is following uncritically the in-house version of the Catholic Church's historiography. Taken at face value, this raises the question of how National Socialism ever succeeded in purely Catholic regions, above all in Bavaria. ${ }^{19}$ If Protestantism is regarded as the spiritual crucible, the proportions are dramatically wrong. If one follows Steigmann-Gall's argumentation, one might think that 'liberal Protestantism' and 'cultural Protestantism' - here simply equated $^{20}$ - were the seedbeds for the völkisch Protestantism of the German Christians and the Christian National Socialists. ${ }^{21}$ This is inconsistent with theological and religious history. The reputable theological seminary of one Adolf von Harnack produced numerous protagonists of the Confessing Church. ${ }^{22}$ Even more significantly, Reinhold Seeberg, his 'modern-positivist' theological opponent at Berlin University who was also Adolf Stoecker's spiritual-religious executor, and other conservative theological strands such as the Erlangen School, the Luther renaissance, the fatal 'theologies of the order of creation' (consistently wrongly cited by Steigmann-Gall as 'creation belief') and many more must have counted as spiritual theological trailblazers for a

sozialismus. Geschichte einer Verstrickung am Beispiel der Evangelisch-Lutherischen Kirche in Bayern (Göttingen 1998); Christoph Weiling, Die 'Christlich-deutsche Bewegung'. Eine Studie zum konservativen Protestantismus in der Weimarer Republik (Göttingen 1998); Manfred Gailus, Protestantismus und Nationalsozialismus. Studien zur nationalsozialistischen Durchdringung des protestantischen Sozialmilieus in Berlin (Cologne 2001); idem, “"Overwhelmed by their own fascination with the 'Ideas of 1933'": Berlin's Protestant Social Milieu in the Third Reich', German History, 20 (2002), no. 4, 462-93; idem, '1933 als protestantisches Erlebnis: emphatische Selbsttransformation und Spaltung', Geschichte und Gesellschaft 29, 2003, 481-511.

19 The heroic historical concept of the domestically generated history of Catholicism is in urgent need of revision. First attempts can be found in critical regional studies: Cornelia RauhKühne, Katholisches Milieu und Kleinstadtgesellschaft. Ettlingen 1918-1939 (Sigmaringen 1991); Thomas Breuer, Verordneter Wandel? Der Widerstreit zwischen nationalsozialistischem Herrschaftsanspruch und traditioneller Lebenswelt im Erzbistum Bamberg (Mainz 1992); Norbert Fasse, Katholiken und NS-Herrschaft im Münsterland. Das Amt Velen-Ramsdorf 1918-1945 (Bielefeld 1996); Oded Heilbronner, Catholicism, Political Culture, and the Countryside. A Social History of the Nazi Party in South Germany (Ann Arbor, MI 1998); Olaf Blaschke, 'Tyrannei und Tradition in der Region. Abweichende Urteile über die Katholiken im Nationalsozialismus', Archiv für Sozialgeschichte, 36 (1996), 471-80; idem, 'Die "Reichspogromnacht" und die Haltung von katholischer Bevölkerung und Kirche', Zeitschrift für Religions- und Geistesgeschichte, 52 (2000), no. 1, 47-74.

20 Nowhere is it explained who and what precisely is meant by 'liberal Protestantism' or 'Kulturprotestantismus'. For clarification see the article 'Liberale Theologie', Religion in Geschichte und Gegenwart, 4th edn, vol. 5 (2002), esp. columns 310-14; and the article 'Kulturprotestantismus', in ibid., vol. 4 (2001), columns 1850-2.

21 This perverse thesis about Liberal Protestantism runs similarly obsessively throughout the book as does his actual thesis. Cf. Steigmann-Gall, Holy Reich, op. cit., esp. 37-41, 78 ff., 85, 263.

22 Mention will only be made here of Karl Barth, Richard Karwehl, Martin Albertz, Günther Dehn, Otto Dibelius, Willy Oelsner, Rudolf Jungklaus and Arthur Rackwitz; see Gailus, Protestantismus und Nationalsozialismus, op. cit., esp. 628; clearly one should refrain from drawing too sharp a line of continuity connecting the liberal pre-war theology with the Confessing Church. 
nationalistic Protestantism. ${ }^{23}$ In any event, any theological historical inference cannot adequately explain the extremely untheological German Christians, a religious-völkisch 'faith movement', who loved 'the Führer' as their Redeemer, the uniform, the marching and the flag. Furthermore, cultural Protestantism was in retreat at the latest from 1910, was weakened by the spiritual-political upheavals of the world war era, and by the time of the Weimar Republic hardly existed.

To allude to another issue: what was the state of 'Christian resistance' to National Socialism? Neither in the introduction nor in the conclusion does Steigmann-Gall discuss this topic, one which can hardly be ignored in the context of his enquiry. I am the last person to overestimate Christian-motivated resistance to National Socialism. There are good reasons to relativize and generally to reduce its importance to below that ascribed to it by postwar apologetic histories of the struggle between Church and State. ${ }^{24}$ But it did exist. If National Socialism was as Christian as the author, here and there, purports to suggest, then why should there have been resistance to it motivated by Christian principles? ${ }^{25}$

Error-spotting does not appeal to me. However if, in the course of reading, one frequently encounters errors, then of necessity one pays closer attention. So considerable is the catalogue of skewed and distorted constructions and misinterpretations, of factual errors and slapdash work that I cannot pass over them without comment. A few examples: Steigmann-Gall wrongly relocates Otto Dibelius's famous Potsdam sermon preached on 'Potsdam Day' to 'Berlin's Nikolai Church' (69). There never was a 'controversy at the German Christian Sportspalast (!) Assembly of November 1933' (73); the whole point of the scandal was that the 20,000 participants at this gathering adopted the offensive völkisch speech and resolution by Reinhold Krause, the German Christians' regional chairman with unanimous enthusiasm (with but one opposing vote!). The ecclesiastical-political storm of protest broke the follow-

23 For Seeberg see Thomas Kaufmann, 'Die Harnacks und die Seebergs. "Nationalprotestantische Mentalitäten" im Spiegel zweier Theologenfamilien', in Gailus and Lehmann (eds), Nationalprotestantische Mentalitäten, op. cit., 165-222. The two parallel family stories are clear in their expression: Ernst von Harnack, Harnack's son, a 'religious socialist', was in the resistance, was arrested after 20 July 1944 and executed on 3 March 1945. Erich Seeberg, like his father a Berlin theologian, was one of the keenest of the nazi professors at the Friedrich-WilhelmsUniversity and was one of the most perfidious string-pullers in National Socialist university and academic politics.

24 In this connection see Gailus, Protestantismus und Nationalsozialismus, op. cit., esp. 17; Georg Denzler, Widerstand ist nicht das richtige Wort. Katholische Priester, Bischöfe und Theologen im Dritten Reich (Zurich 2003).

25 It is unnecessary to note here the extensive source material. Most recently: Hans Günter Hockerts and Hans Maier (eds), Christlicher Widerstand im Dritten Reich (Annweiler 2003); Günther van Norden and Klaus Schmidt (eds), Sie schwammen gegen den Strom. Widersetzlichkeit und Verfolgung rheinischer Protestanten im 'Dritten Reich' (Cologne 2006). 
ing day, led by the Church opposition around Martin Niemöller. The curate's son Horst Wessel did not die 'in a street brawl with the communists in 1930' (76) but in the Berlin-Friedrichshain Hospital some five weeks after being fatally wounded by a gunshot during an assault on him in his flat by a group partly connected with communists. ${ }^{26}$ Steigmann-Gall maintains that the Prussian princes August Wilhelm and Eitel Friedrich had been 'party members since 1930'. While this is correct in the case of 'Auwi', it does not apply to the latter (83). Elsewhere the author maintains that 'members of the Confessing Church' claimed Houston Stewart Chamberlain as their 'intellectual property' in the same way that Rosenberg or the German Christians did. 'Evidence': an obscure indirect quote from Richard Gutteridge's study of the Protestant Church and the Jews; Steigmann-Gall fills in the blanks entirely speculatively: it could be correct but the evidence is lacking. These are illustrations of the slapdash approach to sources and quotations, the overused practice of indirect quotation and the constant tendency to exaggerate interpretations of evidence to fit in with his basic thesis. ${ }^{27}$ Matthes Ziegler, a leading ideological colleague of Rosenberg is described as an 'ex-pastor' and former Protestant theologian (111). In fact, before he went to work for Rosenberg, Ziegler first studied theology and German and later (1932) only folklore (more precisely, ancient Nordic-Germanic studies). ${ }^{28}$ Steigmann-Gall rashly interprets the high excess figures of new Church membership over Church resignations in 1933 and 1934 as a sign of 'religious renewal' (114). In fact, many former Protestants rejoined the Church immediately after 30 January 1933 so as not to be in

26 On the subject of the embedding of Wessel's Protestant family historical biography see Manfred Gailus, 'Vom Feldgeistlichen des Ersten Weltkriegs zum politischen Prediger des Bürgerkriegs. Kontinuitäten in der Berliner Pfarrerfamilie Wessel', Zeitschrift für Geschichtswissenschaft 50 (2002), 9, 773-803.

27 Steigmann-Gall: 'In a 1936 article in the Confessing Church journal Junge Kirche, Chamberlain was described as "outstanding among the confessors of Jesus Christ at the turn of the century"' (101). One's curiosity is awoken and one turns to Gutteridge to see which 'members of the Confessing Church' might have written this. The quotation is not to be found where indicated by Steigmann-Gall (Richard Gutteridge, Open Thy Mouth for the Dumb! The German Evangelical Church and the Jews, 1879-1950 [Oxford 1976], 35). After a long search I found it on p. 25. Further, Gutteridge provides no reference to an author. A reference back to the original (Junge Kirche, 4, 21 March 1936, no. 6, 266 ff.) reveals a brief editorial note on the occasion of the ninth anniversary of Chamberlain's death with no reference to the author. The likelihood is that the editorial note was written by Fritz Söhlmann, a journalist and editor-in-chief of Junge Kirche. Söhlmann, a member of the Christian-völkisch youth movement, was not a theologian. During the second world war Söhlmann practised a strange kind of hyperpatriotic-heroical war commentary, discussing his own plans of völkisch-Protestant settlement in the newly conquered east. He is hardly an appropriate chief witness for 'members of the Confessing Church'.

28 He could have easily looked this up in the ethnological debates of the 1980s about National Socialist folklore: see Hannjost Lixfeld, 'Matthes Ziegler und die Erzählforschung des Amtes Rosenberg. Ein Beitrag zur Ideologie der nationalsozialistischen Volkskunde', Rheinisches Jahrbuch für Volkskunde, 26 (1985/86), 37-59; Wolfgang Brückner, 'Volkskunde als gläubige Wissenschaft. Zum protestantischen Aspekt der ideologischen Wurzeln deutscher VolkskulturKonzepte', in Nils-Arvid Bringéus et al. (eds), Wandel der Volkskultur in Europa, I. Festschrift für Günter Wiegelmann zum 60. Geburtstag (Münster 1988), 17-42. 
danger of being tarred with the brush of red dissidence. Many of these returnees left again in 1936/37 when, once again, it became politically opportune to do so. Steigmann-Gall demonstrates an extraordinary ignorance of the Christian calendar when he describes the Sunday following Ash Wednesday as 'Whit Sunday' (123 ff.). ${ }^{29}$ The paragraph dealing with Church-political events in autumn 1933 is totally inaccurate (164): it was the Brown Synod (Prussian General Synod) convened on 5 September in Berlin, not the National Synod convened on 27 September in Wittenberg, which passed the ecclesiastical Aryan clause which prompted the opposing Synod members to resign in protest. In contrast, the National Synod provided the grotesque spectacle of the unopposed acclamation of the new nazi Reich Bishop Müller. The German Christians (DC) conference convened in November in the Berlin Sportpalast was not a 'national DC conference' but a Members' General Meeting of the German Christians, Greater Berlin Region. The Pastors' Emergency League had already been founded on 11 September 1933 (and not solely by Niemöller; significant co-founders were the pastors Eugen Weschke and Günter Jacob), not in response to the aforementioned German Christians' conference but as a riposte to the Aryan clause only recently passed by the Brown Prussian Synod. It would be easy to continue with this catalogue of exaggerated or inaccurate interpretations, absence of precision and errors. I refrain from doing so in the interest of saving space and in order not to be accused of carping.

Despite considerable reservations and omissions, Steigmann-Gall's study makes an interesting, stimulating and at times provocative book. I agree entirely with his assessment of the presence and effectiveness of National Socialist Christians, particularly in the Protestant milieu. I would estimate that a third of the contemporary Protestant milieu belonged to these dual-faith inner ecclesiastical circles..$^{30} \mathrm{I}$ am less convinced about the presence and prominence of Christian National Socialists, particularly in the Party leadership. They certainly existed but more so in the lower and middle ranks of the NSDAP; if they were present in the upper echelons, it was only here and there and usually in diluted form. 'Conceptions of Christianity' cannot seriously be applied to this group; a more appropriate description would be dual faith side by side with shrinking remnants of Christianity. All in all, 'Christian' for this category of persons was in religious atrophy. It was no coincidence that the longer the regime was in power, the more prominent explicit Christian

29 Ash Wednesday denotes the Wednesday before the first Sunday of Lent (which normally falls in February!); in the cited context (April 1935), the author (who has confused Easter with Whitsun) presumably intended to refer to the Wednesday of Holy Week, in other words prior to Easter Sunday.

30 See, using the example of approx. 15 Protestant regional cultures, Manfred Gailus and Wolfgang Krogel (eds), Von der babylonischen Gefangenschaft der Kirche im Nationalen. Protestantismus, Nationalsozialismus und Nachkriegsgeschichte 1930 bis 2000 (Berlin 2006). 
National Socialists, for example the Reich Minister for Church Affairs Hanns Kerrl, found themselves in increasingly marginalized, not to say feud-ridden, territory. ${ }^{31}$ Meanwhile the 'ideological dogmatists' (Wolfgang Dierker) around Himmler and Heydrich, Rosenberg and Bormann, who wanted to force a breach in religious historical mentality, were clearly on the advance. This is clearly reflected in the increasing proportion of 'Deists' (Gottgläubige) in the Party, the SS and other subdivisions, at any rate until 1943/44. The dynamic of the 'new faith', predominantly non-Christian, only began to unfold in the later years of the regime, particularly from the early astonishing war successes to the turning point of the war in 1942/43. It cascaded from the top down through the party structure and spread gradually, without, of course, penetrating as an entity in National Socialist society. From a religious-historical point of view the permanent establishment of a 'new faith' requires broader historical perspectives. However, the newly awakened National Socialism which began in about 1920 and in 1933, as a ruling party controlling the German state, became a völkisch-political faith movement in the name of the 'Aryan-Germanic race' - came to an end after 12 years in power.

Manfred Gailus

is a Professor of Modern History at the Technical University of Berlin. He is the author of Protestantismus und Nationalsozialismus. Studien zur nationalsozialistischen Durchdringung des protestantischen Sozialmilieus in Berlin (Cologne 2001) and editor, with Wolfgang Krogel, of Von der babylonischen Gefangenschaft der Kirche im Nationalen. Regionalstudien zu Protestantismus, Nationalsozialismus und Nachkriegsgeschichte 1930 bis 2000 (Berlin 2006). He is currently working on religious and social history, and Protestantism in nineteenth and twentieth centuries.

31 For Kerrl see Heike Kreutzer, Das Reichskirchenministerium im Gefüge der nationalsozialistischen Herrschaft (Düsseldorf 2000), 99 ff. Here, too, the Goebbels diaries proved a mine of relevant source material. 